\title{
Control of methionine biosynthesis in Escherichia coli K12: a closer study with analogue-resistant mutants
}

\author{
M. K. Chattopadhyay, A. K. Ghosh and S. Sengupta* \\ Department of Applied Biochemistry, Indian Institute of Chemical Biology, 4 Raja S. C. Mullick Road, \\ Calcutta 700032, India
}

(Received 16 February 1990; revised 28 September 1990; accepted 3 December 1990)

\begin{abstract}
Control of methionine biosynthesis in Escherichia coli K12 was reinvestigated by using methionine-analogueresistant mutants. Norleucine (NL) and $\alpha$-methylmethionine (MM) were found to inhibit methionine biosynthesis directly whereas ethionine (Et) competitively inhibited methionine utilization. Adenosylation of Et to generate $S$ adenosylethionine (AdoEt) by cell-free enzyme from $E$. coli $\mathrm{K12}$ was demonstrated. Tolerance of increasing concentrations of $N L$ by $E$. coli $K 12$ mutants is expressed serially as phenotypes $N L^{R}, N L^{R} E^{R}, N L^{R} M M^{R}$ and finally $\mathrm{NL}^{\mathrm{R}} \mathbf{E t}^{\mathrm{R}} \mathrm{MM}^{\mathrm{R}}$. All spontaneous $\mathrm{NL}^{\mathrm{R}}$ mutants had a met $K$ mutation, whereas NTG-induced mutants had mutations in both the met $K$ and met $J$ genes. The kinetics of methionine adenosylation by the $E$. coli $\mathrm{K} 12$ cell-free enzyme were found to be similar to those reported for the yeast enzyme, showing the typical lag phase at low methionine concentration and disappearance of this phase when AdoMet was included in the incubation mixture. NL extended the lag phase, and lowered the rate of subsequent methionine adenosylation, but did not affect the shortening of the lag phase of adenosylation by AdoMet.
\end{abstract}

\section{Introduction}

In Escherichia coli, the genes of the methionine regulon are distributed throughout the chromosome (Bachmann, 1983). The regulatory functions of $S$-adenosylmethionine (AdoMet) as co-repressor and of the met $J$ gene product as aporepressor have been confirmed by studying in vitro expression of some of the $E$. coli methionine biosynthesis genes (Shoeman et al., 1985a,b). However, none of the met $J$ and $m e t K$ (see Fig. 1) regulatory mutants isolated (Su et al., 1970; Kung et al., 1972; Greene et al., 1970, 1973) were fully decontrolled for methionine production. The non- $\mathrm{B}_{12}$-dependent transmethylation step which is one of the two convergent routes for methionine biosynthesis (Fig. 1), synthesizing the methyl group from serine, was also found to be under the same repressor control (Smith, 1971). The regulatory roles of MetJ protein and AdoMet in the expression of the 5,10methylenetetrahydrofolate reductase gene (Shoeman et al., 1985a) and of AdoMet in the synthesis of serine hydroxymethyltransferase have been demonstrated (Greene \& Radovich, 1975, Dev \& Harvey, 1984). In this paper, we report a reinvestigation of the methionine control system by studying spontaneously occurring

Abbreviations: AdoEt, $S$-adenosyl-DL-ethionine; AdoMet, $S$-adenosyl-L-methionine; Et, DL-ethionine; MM, $\alpha$-methyl-DL-methionine; NL, DL-norleucine. methionine-analogue-resistant mutants of $E$. coli $\mathrm{K} 12$, with the hope that mutants thus isolated might have a single locus altered among the large numbers of loci involved in the overall control of methionine biosynthesis and might thereby yield a better understanding of the control mechanism.

\section{Methods}

Bacterial strains and growth conditions. Escherichia coli $\mathrm{K} 12$ strains (see Table 1) and phage P1 were obtained from the E. coli Genetic Stock Center, Yale University School of Medicine, New Haven, CT, USA. Minimal medium was that of Davis \& Mingioli (1950) with $1 \%$ $(w / v)$ glucose. Cells were grown in shake flasks at $37^{\circ} \mathrm{C}$.

Chemicals. $N$-Methyl- $N^{\prime}$-nitro- $N$-nitrosoguanidine (NTG) was obtained from Fluka. DL-Ethionine (Et), DL-norleucine (NL), $\alpha$-methylDL-methionine (MM), $S$-adenosyl-L-methionine (AdoMet), $S$-adenosylDL-ethionine (AdoEt) and ATP (sodium salt) were purchased from Sigma. SP-Sephadex (C-25) was obtained from Pharmacia. $\left[{ }^{35}\right.$ S]Methionine was obtained from the Bhabha Atomic Research Centre, Bombay, India.

Determination of minimum inhibitory concentrations (MICs) of methionine analogues and selection of analogue-resistant mutants. MIC values were determined by dilution in minimal medium. To obtain analogueresistant mutants in liquid medium, cells from the mid-exponential phase were harvested, washed and suitably diluted with saline, and inoculated into analogue-containing minimal medium (AM) at an initial population of approximately $10^{5}$ cells $\mathrm{ml}^{-1}$, growth being permitted up to $72 \mathrm{~h}$. For mutant isolation on solid medium, 


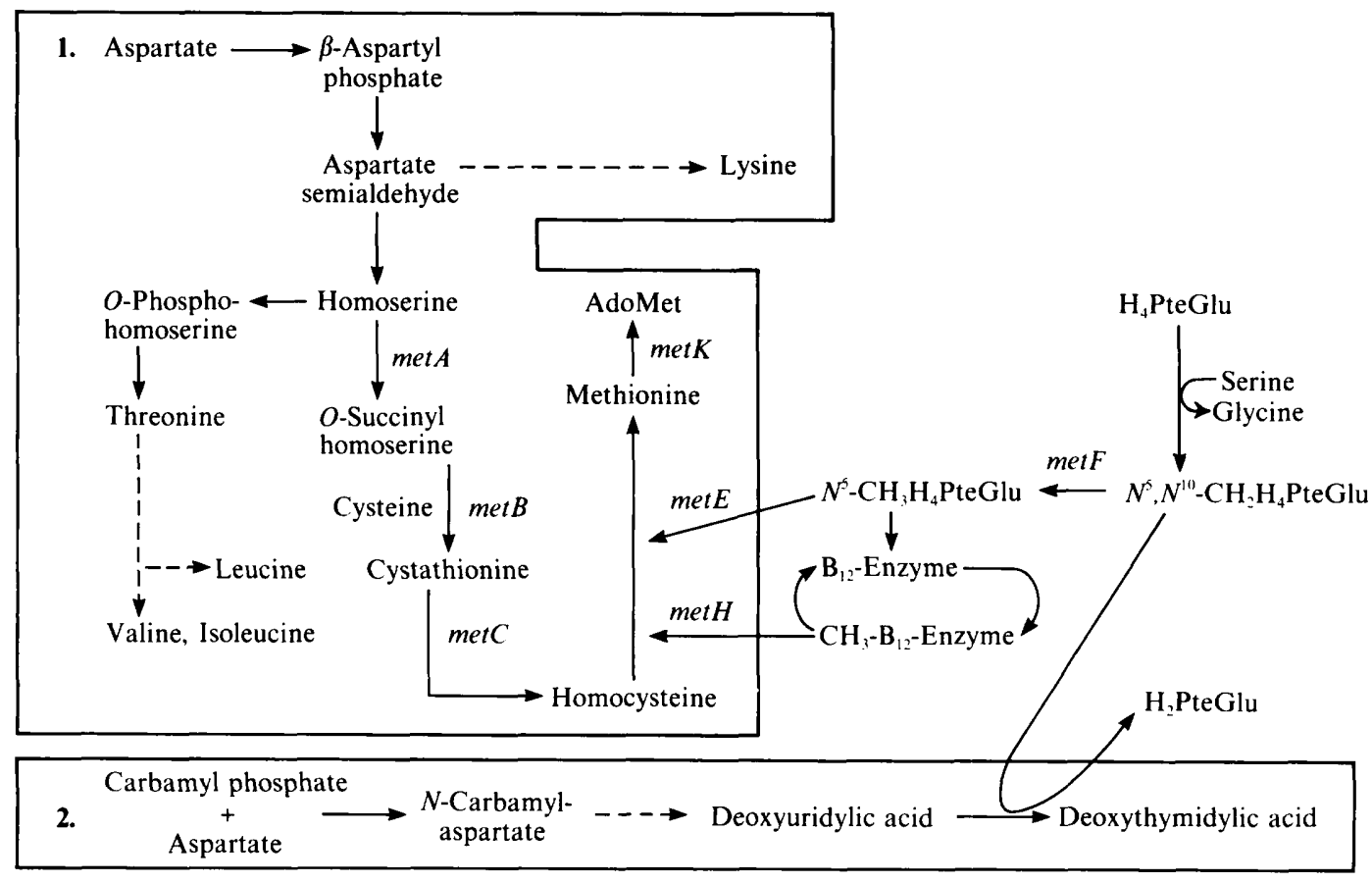

3. Thymine + Deoxyribose 1-phosphate $\longrightarrow$ Deoxythymidine $\longrightarrow$ Deoxythymidylic acid

Fig. 1. Outline of the biosynthetic pathways of methionine, methyl group and deoxythymidylic acid in $E$. coli. $\mathbf{H}_{4}$ PteGlu, tetrahydropteroyl mono- or triglutamate; AdoMet, $S$-adenosyl- $L$-methionine. Genes: met $A$, homoserine- $O$-transsuccinylase (EC 2.3.1.46); met $B$, cystathionine- $\gamma$-synthase (EC 4.2.99.9); metC, $\beta$-cystathionase (EC 4.4.1.8); met $E, N^{5}$-methyltetrahydropteroyltriglutamate-homocysteine methyltransferase (cobalamine independent) (EC 2.1.1.14); met $F, N^{5}, N^{10}$-methylenetetrahydrofolate reductase (EC 1.1.99.5); $\mathrm{met} H, N^{5}$-methyltetrahydrofolate-homocysteine methyltransferase (cobalamine dependent) (EC 2.1.1.13); $m e t K$, methionine adenosyltransferase (EC 2.5.1.6).

Table 1. Genotypes of recipient strains used for PI transduction

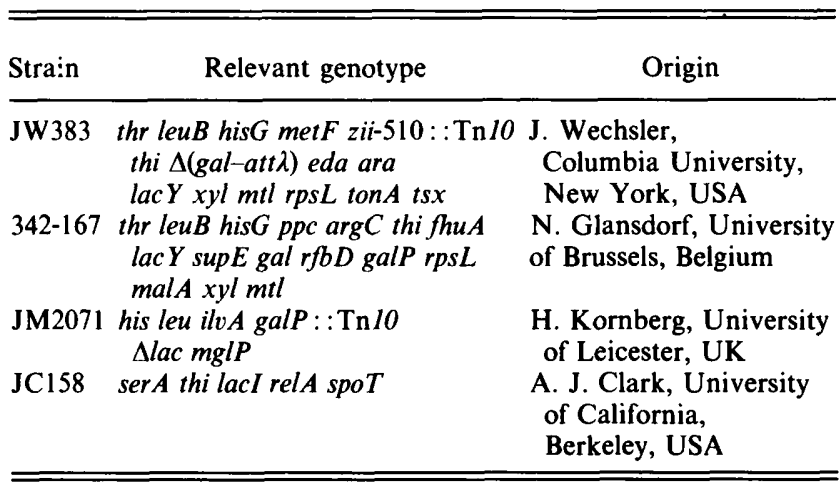

exponentially growing cells were washed and plated directly on AM agar plates. After $72 \mathrm{~h}$, colonies were transferred to slants of the same medium. NTG mutagenesis was carried out at $30 \mu \mathrm{g} \mathrm{ml}^{-1}$ according to Adelberg et al. (1965). NTG-treated cells were grown overnight in AM broth, and the cultures diluted and plated on agar plates of the same medium. Cross-resistance was checked by streaking the overnight growth of mutants on various AM agar plates. Mutant loci of representatives of phenotypic classes of resistant mutants were determined by transduction with phage Plkc according to Miller (1972).
Identification of amino acids. Cells were grown in minimal medium with $1 \%(w / v)$ glucose at $37^{\circ} \mathrm{C}$ for $48 \mathrm{~h}$ and $100 \mu \mathrm{l}$ volumes of centrifuged culture filtrates were spotted on Whatman no. 1 paper. Ascending paper chromatography was then carried out with nbutanol/acetic acid/water ( $4: 1: 1$, by vol.). Amino acids were detected with ninhydrin reagent.

$A T P$ : L-methionine-S-adenosyltransferase (methionine adenosyltransferase, EC 2.5.1.6) assay. (a) Enzyme source. Cell extracts containing the enzyme were obtained by ammonium sulphate fractionation of cellfree lysates of $E$. coli K 12 (Tabor \& Tabor, 1971). Cells were grown in minimal medium containing $0 \cdot 2 \%(\mathrm{w} / \mathrm{v})$ glucose for $10-12 \mathrm{~h}$. The harvested cells were suspended in glucose-free minimal medium $(25 \mathrm{~g}$ wet wt per $100 \mathrm{ml}$ ) and the suspension was sonicated at an amplitude of $10 \mu \mathrm{m}$ for $15 \mathrm{~min}$. The lysate was centrifuged at $13000 \mathrm{~g}$ for $15 \mathrm{~min}$; $5 \%(\mathrm{w} / \mathrm{v})$ streptomycin sulphate solution was added to the supernatant in equal volume and the precipitate discarded. The supernatant was mixed with half its volume of saturated ammonium sulphate solution, and the mixture left for $1 \mathrm{~h}$ with occasional stirring. The supernatant after centrifugation was further mixed with half its volume of saturated ammonium sulphate solution and the mixture left for $\mathbf{4 5} \mathrm{min}$ and then centrifuged. The final precipitate was collected, dissolved in $0.01 \mathrm{M}-$ potassium phosphate buffer, $\mathrm{pH} 7 \cdot 2$, and the solution used as the source of enzyme. All the steps were carried out at $4{ }^{\circ} \mathrm{C}$.

(b) Enzyme assay. Enzyme activity was assayed in two sets of duplicates. The incubation mixture comprised $0.5 \mathrm{ml}$ of $0.21 \mathrm{M}$ triethanolamine sulphate buffer, $\mathrm{pH} 8.2$, containing $3.87 \mu \mathrm{mol}$ methionine, $8.0 \mu \mathrm{mol} \mathrm{ATP,} 6.0 \mu \mathrm{mol} \mathrm{NaCN}, 30 \mu \mathrm{mol} \mathrm{MgSO}_{4}$, and cell 
extract $\left(40 \mu \mathrm{g}\right.$ protein). Incubation was carried out for $30 \mathrm{~min}$ at $37^{\circ} \mathrm{C}$, the reaction being terminated by the addition of $1.1 \mathrm{ml}$ ice-cold $0.34 \mathrm{M}$ $\mathrm{HCl}$. The incubation mixtures were kept on ice and applied to an SPSephadex (C-25) column $(6 \mathrm{~mm} \times 60 \mathrm{~mm}$ ). Reaction products (adenosylated methionine or ethionine) were eluted from the column by 500 $\mathrm{mM}-\mathrm{HCl}$ (Glazer \& Peale, 1978) and estimated by their absorbance at $260 \mathrm{~nm}$ using a Beckmann Spectrophotometer.

Adenosylated amino acids were characterized by paper chromatography and UV spectrometry and compared to authentic samples. Solvent systems (Park, 1958) used in paper chromatography were nbutanol/glacial acetic acid/water $(60: 15: 25$, by vol.) and ethanol/glacial acetic acid/water $(65: 1: 34$, by vol.).

The effects of NL or AdoMet on the kinetics of methionine adenosylation by the enzyme were studied using the same incubation mixture, containing ${ }^{35}$ S $]$ methionine $\left(0.92 \mathrm{Ci} \mathrm{mol}^{-1} ; 34 \mathrm{GBq} \mathrm{mol}^{-1}\right)$. After 10 min preincubation, reactions were initiated by the addition of methionine; they were terminated at various intervals. Fractions containing AdoMet were eluted from an SP-Sephadex column by $500 \mathrm{mM}-\mathrm{HCl}$ and the amount of radioactivity present in each fraction was measured by liquid scintillation counting in a Beckman LS 1800 counter using Bray's solution. Blank tubes were similar except that $\left[{ }^{35} \mathrm{~S}\right]$ methionine was added after the addition of $1.1 \mathrm{ml}$ of ice cold $0.34 \mathrm{M}-\mathrm{HCl}$. Amounts of radioactivity present in the experimental tubes were always corrected by subtracting the amount of radioactivity present in the blanks. Protein was estimated by the Lowry method.

\section{Results and Discussion} Inhibition of the growth of $E$. coli $K 12$ by methionine
analogues

Although mutants of $E$. coli surviving in the presence of Et, MM and NL were characterized long ago as methionine biosynthetic regulatory mutants, the exact mechanism of action of these analogues, other than that of $\mathrm{MM}$, on methionine biosynthetic enzymes (Schlesinger, 1967) was not definitely known. MICs of these analogues for $E$. coli $\mathrm{K} 12$ were found to be $3.0 \mu \mathrm{g} \mathrm{ml}^{-1}$, 4-5 $\mu \mathrm{g} \mathrm{ml}^{-1}$ and 2-2.5 $\mathrm{mg} \mathrm{ml}^{-1}$ for MM, NL and Et respectively. The MICs of NL and MM increased exponentially with increase in inoculum size, while that of Et did not alter significantly under similar conditions (Fig. 2). On the other hand, when L-methionine at concentrations of $7-8 \mu \mathrm{g} \mathrm{ml}^{-1}$ was added to plates containing $\mathrm{NL}$ and $\mathrm{MM}$ at various concentrations (up to $50 \mu \mathrm{g} \mathrm{ml}^{-1}$ ), about $50 \%$ colonies were generated compared to analogue-free control plates $\left(1 \pm 0.02 \times 10^{3}\right.$ colonies per plate). Under similar conditions, graded amounts of L-methionine from $150 \mu \mathrm{g} \mathrm{ml}^{-1}$ to $1 \mathrm{mg} \mathrm{ml}^{-1}$ had to be added to plates to restore approximately $50 \%$ colony generation in the presence of $2-4 \mathrm{mg} \mathrm{Et} \mathrm{ml}^{-1}$. These observations indicated that NL and MM probably inhibited methionine biosynthesis in $E$. coli directly, so that supplementation of the required amount of methionine was sufficient to antagonize activity of NL and MM even in 10-15-fold excess of their growth inhibitory concentrations. However, the higher concentrations of Lmethionine required to antagonize the activity of Et

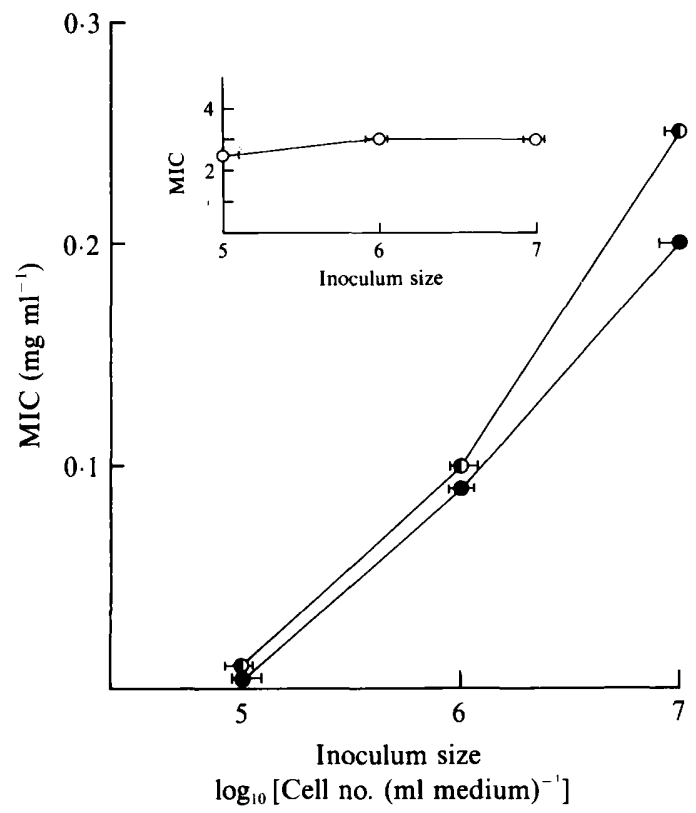

Fig. 2. Variation in MIC values of methionine analogues with changes in inoculum size. E. coli cells were grown at $37^{\circ} \mathrm{C}$ in minimal medium in shake flasks for both inoculum preparation and growth. A $1 \%(\mathrm{v} / \mathrm{v})$ inoculum was added to each analogue-containing medium and growth was measured at $660 \mathrm{~nm}$. $\bullet, \mathrm{MM} ; 0, \mathrm{NL} ; \mathrm{O}$, Et. The error bars indicate \pm SD of three sets of duplicate experiments. Units for the inset are the same as those for the main figure.

suggested that Et probably did not inhibit methionine biosynthesis directly, but competitively inhibited utilization of methionine. AdoMet may be considered as one of the essential metabolites derived by the cell from methionine. In this context, it may be noted that Et was reported to be freely adenosylated by yeast methionine adenosyltransferase (Park, 1958), but not by the cell-free enzyme from $E$. coli (Peterkofsky, 1965).

\section{AdoEt formation by E. coli K12 enzyme}

Reports on the adenosylation of Et by $E$. coli enzyme are contradictory. Martin \& Moo-Pen (1963), in their studies on Et resistance of $E$. coli, concluded that the organism could adenosylate Et. However, Peterkofsky (1965) could not detect AdoEt formation by $E$. coli cell-free lysate. In view of the above suggestion that Et may compete with methionine in the synthesis of an essential methionine-derived product, we reinvestigated Et adenosylating activity in an $E$. coli cell extract. Fig. 3 shows the kinetics of adenosylation of Et and/or methionine by the enzyme as a function of amino acid concentration. The results indicated that the enzyme from $E$. coli $\mathrm{K} 12$ could freely adenosylate Et, though at a slightly lower rate than methionine. Thus Et might not compete with methionine in the formation of AdoMet in $E$. coli, but the adenosylated product AdoEt might compete with the 


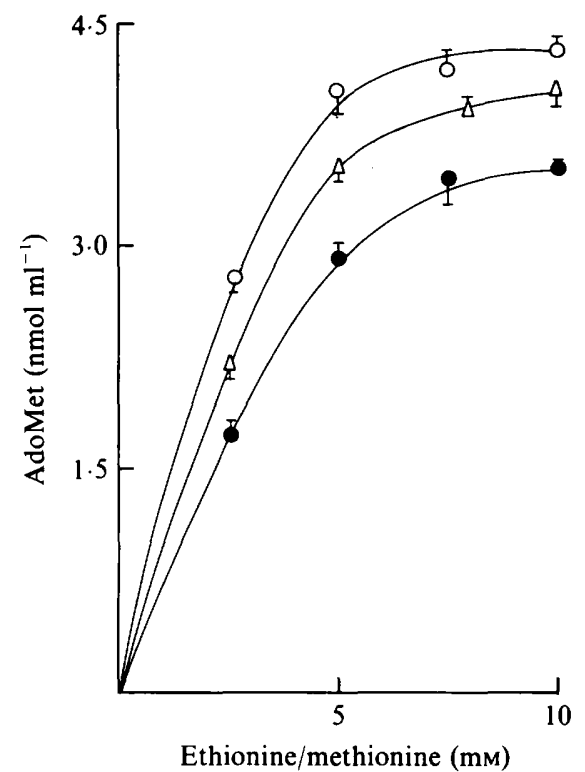

Fig. 3. Adenosylation of Et and methionine by cell-free extract of $E$. coli $\mathrm{K} 12$. Reaction mixture contained variable amounts of $\mathrm{Et}$, of Lmethionine, or of an equivalent mixture of both, $8.0 \mu \mathrm{mol}$ ATP, $6.0 \mu \mathrm{mol} \mathrm{NaCN}, 30 \mu \mathrm{mol} \mathrm{MgSO}_{4}$, and enzyme-containing protein $(40 \mu \mathrm{g})$ in $0.5 \mathrm{ml} 0.21 \mathrm{M}$-triethanolamine sulphate buffer, $\mathrm{pH} 8.2$. The mixtures were incubated for $30 \mathrm{~min}$ at $37^{\circ} \mathrm{C}$. Reaction was terminated by the addition of $1.1 \mathrm{ml}$ ice-cold $0.34 \mathrm{M}-\mathrm{HCl}$ and adenosylated ethionine and/or methionine were isolated by SP-Sephadex chromatography as described in Methods. Adenosylated amino acids were estimated by determining absorbance at $260 \mathrm{~nm}\left(\varepsilon=154001 \mathrm{~mol}^{-1}\right.$ $\left.\mathrm{cm}^{-1}\right) . \mathrm{O}, \mathrm{L}$-methionine; $\triangle$, equimolar mixture of $\mathrm{L}$-methionine and $\mathrm{Et}$; - Et. The error bars indicate \pm SD of three sets of duplicate experiments. corepresser AdoMet for the binding site of the aporepressor.

\section{Phenotypes of spontaneously occurring methionine-} analogue-resistant mutants of E. coli K12

The methionine regulatory met $J$ and $m e t K$ mutants and feedback resistant met $A$ mutants of $E$. coli were known long ago. The phenotypes of met $K$ mutants were of both methionine overproducer and non-producer types, whereas metJ mutants were all overproducers (Smith, 1971). However, the mechanisms for the survival of metJ or met $K$ mutants in the presence of Et or other analogues were not clear. In the present study we attempted to analyse the phenotypes of all spontaneously occurring methionine-analogue-resistant mutants of $E$. coli $\mathrm{K} 12$ as a function of their analogue tolerance limits and spectra.

It was observed (Table 2) that MM and Et specifically selected two groups of mutants with phenotypes similar to those of metA and metJ mutants. None of the $\mathrm{MM}^{\mathrm{R}}$ mutants overproduced methionine or any other amino acid, though they were expected to be feedback-resistant for methionine biosynthesis (Schlesinger, 1967). In the situation when repression control of methionine biosynthesis in E. coli $\mathrm{K} 12$ is more effective than feedback control, or end-products other than methionine are required for feedback control, overproduction of

Table 2. Cross-resistance and amino acid overproduction by the analogue-resistant mutants of $E$. coli $\mathrm{K} 12$

On average, 15-20 colonies of each mutant type were tested for analogue cross-resistance and also for amino acid production in minimal medium. Mutants resistant to Et had two types of amino acid excretion patterns, whereas mutants with lower NL tolerance $\left(25 \mu \mathrm{g} \mathrm{ml}^{-1}\right)$ excreted Thr and Met only. Frequency was determined for all the survivors irrespective of their subclasses. Lys, lysine; Thr, threonine; Met, methionine.

\begin{tabular}{|c|c|c|c|}
\hline $\begin{array}{l}\text { Analogue } \\
\text { ( } \mu \mathrm{g} \text { per ml of } \\
\text { selection medium) }\end{array}$ & $\begin{array}{l}\text { Mean } \\
\text { frequency of } \\
\text { occurrence* }\end{array}$ & $\begin{array}{l}\text { Cross-resistance } \\
\text { type (maximum } \\
\text { tolerance dose, } \\
\left.\quad \mu \mathrm{g} \mathrm{ml}^{-1}\right)\end{array}$ & $\begin{array}{l}\text { Amino acid } \\
\text { excretion } \\
\text { patterns }\end{array}$ \\
\hline $\begin{array}{ll}\text { Et } & (2000) \\
& (3000)\end{array}$ & $2 \pm 0.5 \times 10^{-5}$ & Et $(3000)$ & $\begin{array}{l}\text { (i) Lys, Thr, Met } \\
\text { (ii) Thr, Met }\end{array}$ \\
\hline MM (10), (20), (50) & $3.02 \pm 1 \cdot 1 \times 10^{-7}$ & MM (50) & Nil \\
\hline NL (10) & $3 \pm 0.2 \times 10^{-7}$ & $\begin{array}{l}\text { (i) NL (25) } \\
\text { (ii) NL (50), Et }(3000) \\
\text { NL (50), MM }(50) \\
\text { NL (50), MM(50), Et }(3000)\end{array}$ & $\begin{array}{l}\text { (i) Thr, Met } \\
\text { (ii) Lys, Thr, Met }\end{array}$ \\
\hline NL (25) & $8 \pm 0.8 \times 10^{-7}$ & $\begin{array}{l}\text { NL (50) } \\
\text { NL (50), MM (50) } \\
\text { NL (50), MM (50), Et (3000) } \\
\text { NL (50), MM (50), Et }(4000)\end{array}$ & $\begin{array}{l}\text { (i) Thr, Met } \\
\text { (ii) Lys, Thr, Met }\end{array}$ \\
\hline NL (50) & $7 \cdot 2 \pm 1 \times 10^{-8}$ & MM (50), NL (100), Et (3000) & $\begin{array}{l}\text { (i) Thr, Met } \\
\text { (ii) Lys, Thr, Met }\end{array}$ \\
\hline $\begin{array}{l}\text { NTG induced } \\
\left(30 \mu \mathrm{g} \mathrm{ml}^{-1}\right)\end{array}$ & & $\begin{array}{l}\text { MM (50), NL (100), Et }(3000) \\
\text { MM (50), NL (100), Et }(4000)\end{array}$ & $\begin{array}{l}\text { (i) Thr, Met } \\
\text { (ii) Lys, Thr, Met }\end{array}$ \\
\hline
\end{tabular}

* Means of three determinations, \pm SD. 
Table 3. Mapping of mutations in the methionine analogue resistant mutants of E. coli K12

Donor strains were representative mutants of $E$. coli $\mathrm{K} 12$ with different phenotypes within the mutant subgroups as described in Table 2. More than 100 colonies of transformants for each set of experiments were screened for the unselected marker. Three different clones of each phenotypic class were used as donors in each set of experiment.

\begin{tabular}{|c|c|c|c|c|}
\hline Donor phenotype & Recipient & $\begin{array}{l}\text { Selected } \\
\text { marker }\end{array}$ & $\begin{array}{l}\text { Unselected } \\
\text { marker }\end{array}$ & Linkage $(\%)$ \\
\hline 1. $\mathrm{Et}_{3000}\left(m e t F^{+} p p c^{+}\right)$ & $\begin{array}{r}\mathrm{JW} 383 \\
342-167 \quad\left(m e t F, \mathrm{Et}^{\mathrm{s}}\right) \\
\left(p p c, \mathrm{Et}^{\mathrm{s}}\right)\end{array}$ & $\begin{array}{l}\mathrm{Met}^{+} \\
\text {Asp }^{+}\end{array}$ & $\begin{array}{l}E t^{R} \\
E t^{R}\end{array}$ & $\begin{array}{l}94 \\
92\end{array}$ \\
\hline 2. $\mathrm{MM}_{50}\left(\operatorname{argC} C^{+} t h i^{+}\right)$ & $\begin{array}{r}342-167 \quad\left(\operatorname{argC}, \mathbf{M M}^{\mathrm{s}}\right) \\
\mathrm{JW} 383 \quad\left(\text { thi, } \mathbf{M M}^{\mathrm{s}}\right)\end{array}$ & $\begin{array}{l}\mathrm{Arg}^{+} \\
\mathrm{Thi}^{+}\end{array}$ & $\begin{array}{l}\mathbf{M M}^{\mathrm{R}} \\
\mathbf{M M}^{\mathrm{R}}\end{array}$ & $\begin{array}{l}34 \\
80\end{array}$ \\
\hline 3. $\mathrm{NL}_{25}\left(\mathrm{galP}^{+} \operatorname{ser}^{+}\right)$ & $\begin{aligned} \mathrm{JM} 2071 & \left(\mathrm{gal} P, \mathrm{NL}^{\mathrm{S}}\right) \\
\mathrm{JC158} & \left(\operatorname{ser} A, \mathrm{NL}^{\mathrm{S}}\right)\end{aligned}$ & $\begin{array}{l}\mathrm{Gal}^{+} \\
\mathrm{Ser}^{+}\end{array}$ & $\begin{array}{l}\mathrm{NL}^{\mathrm{R}} \\
\mathrm{NL}^{\mathrm{R}}\end{array}$ & $\begin{array}{l}84 \\
87\end{array}$ \\
\hline 4. $\mathrm{NL}_{50} \mathrm{MM}_{50}\left(\mathrm{galP}^{+} \mathrm{ser}^{+}\right)$ & $\begin{aligned} \mathrm{JM}^{2071} & \left(\mathrm{galP}, \mathrm{NL}^{\mathrm{S}}\right) \\
\mathrm{JC} 158 & \left(\operatorname{ser} A, \mathrm{NL}^{\mathrm{S}}\right)\end{aligned}$ & $\begin{array}{l}\mathrm{Gal}^{+} \\
\mathrm{Ser}^{+}\end{array}$ & $\begin{array}{l}\mathrm{NL}^{\mathrm{R}} \mathbf{M M}^{\mathrm{R}} \\
\mathrm{NL}^{\mathrm{R}} \mathbf{M M}^{\mathrm{R}}\end{array}$ & $\begin{array}{l}84 \\
90\end{array}$ \\
\hline 5. $\mathrm{NL}_{50} \mathrm{Et}_{3000}\left(\mathrm{galP}^{+} \mathrm{ser}^{+}\right)$ & $\begin{aligned} \mathrm{JM} 2071 & \left(\mathrm{galP}, \mathrm{NL}^{\mathrm{S}}\right) \\
\mathrm{JC} 158 & \left(\operatorname{ser} A, \mathrm{NL}^{\mathrm{S}}\right)\end{aligned}$ & $\begin{array}{l}\mathrm{Gal}^{+} \\
\mathrm{Ser}^{+}\end{array}$ & $\begin{array}{l}N^{R}{ }^{R} t^{R} \\
N^{R} E^{R}\end{array}$ & $\begin{array}{l}89 \\
87\end{array}$ \\
\hline $\begin{array}{l}\text { 6. } \mathrm{NL}_{50} \mathrm{MM}_{50} \mathrm{Et}_{3000} \\
\text { (spontaneous) } \\
\text { (galP }{ }^{+} \text {ser } A^{+} \text {) }\end{array}$ & $\mathrm{JC1} 58\left(\operatorname{ser} A, \mathrm{NL}^{\mathrm{S}}\right)$ & $\mathrm{Ser}^{+}$ & $\mathrm{NL}^{\mathrm{R}} \mathbf{M M}^{\mathrm{R}} \mathrm{Et}^{\mathrm{R}}$ & 89 \\
\hline 7. $\begin{array}{l}\mathrm{MM}_{50} \mathrm{NL}_{100} \mathrm{Et}_{4000} \\
\left(\mathrm{metF}^{+} \operatorname{ser}^{+}\right)\end{array}$ & $\begin{array}{l}\mathrm{JW} 383\left(\operatorname{met} F, \mathrm{Et}^{\mathrm{S}}\right) \\
\mathrm{JC} 158\left(\operatorname{ser} A, \mathrm{NL}^{\mathrm{S}}\right)\end{array}$ & $\begin{array}{l}\mathrm{Met}^{+} \\
\mathrm{Ser}^{+}\end{array}$ & $\begin{array}{l}N^{S} \mathbf{M M}^{\mathrm{S}} E t^{\mathrm{R}} \\
\mathrm{NL}^{\mathrm{R}} \mathbf{M M}^{\mathrm{R}} \mathrm{Et}^{\mathrm{R}}\end{array}$ & $\begin{array}{l}91 \\
84\end{array}$ \\
\hline
\end{tabular}

methionine may not take place in these mutants. Thus, the involvement of AdoMet in feedback inhibition of homoserine transsuccinylase, as reported by Lee $e t$ al. (1966), was supported by our investigation.

The met $J$ mutants were methionine overproducers but were sensitive to feedback inhibition exerted by the methionine analogue MM. However, these mutants did not accumulate homoserine in the culture filtrate in spite of constitutive expression of the methionine biosynthetic enzymes. We have observed that $E$. coli K12 could adenosylate Et to generate AdoEt which might act as a false corepressor. Any mutation which altered the structure of MetJ protein, affecting its binding either to AdoMet or to operator DNA in its active repressor form, would be selected in presence of Et. Thus the metJ mutant would have more AdoMet in the cell pool, as reported by Meedel \& Pizer (1974). If both AdoMet and methionine are involved in the feedback inhibition, MM could inhibit growth of met $J$ mutants when there was sufficient AdoMet present in the cell pool.

The phenotypes of mutants surviving in the presence of increasing concentrations of NL were found to be distinctly different (Table 2): (i) mutants which could tolerate limited concentrations of $\mathrm{NL}$ had mixed phenotypes such as $\mathrm{NL}^{\mathrm{R}}$, $\mathrm{NL}^{\mathrm{R}} \mathrm{Et}^{\mathrm{R}}$ or $\mathrm{NL}^{\mathrm{R}} \mathrm{MM}^{\mathrm{R}}$, and (ii) mutants with higher $\mathrm{NL}$ tolerance had mostly $\mathrm{NL}^{\mathrm{R}} \mathrm{Et}^{\mathrm{R}} \mathrm{MM}^{\mathrm{R}}$ phenotypes similar to met $K$ mutants. However, all these NL-resistant phenotypes escaped detection in Et- or MM-containing plates, possibly due to their lower frequencies of occurrence than metJ and metA mutants (Table 2).
Mutagenesis of E. coli K12 by NTG followed by screening of the survivors in the presence of all the different concentrations of MM, Et and NL, predominantly selected $\mathrm{MetK}^{-}$phenotype mutants irrespective of the analogue or the concentration used for screening. It appeared that the $\mathrm{MetK}^{-}$phenotype was the ultimate for mutants surviving in the presence of high concentrations of methionine analogues. It was subsequently observed (see below) that most of the NTG-induced metK mutants were genetically different from the spontaneously occurring mutants of similar phenotype (Table 3 ) in having an additional mutation in the met $J$ gene.

\section{Characterization of genotypes of methionine-analogue- resistant mutants}

It was observed that the spontaneous $\mathrm{Et}^{\mathrm{R}}$ mutants were of met $J$ genotypes, since their resistance marker was more than $90 \%$ co-transducible with the $\operatorname{met} F(89 \mathrm{~min})$ and ppc (89 min) genes during P1 transduction (Table 3). $\mathrm{MM}^{\mathrm{R}}$ mutants selected in the presence of $\mathrm{MM}$ had a met $A$ genotype, since their resistance marker was $80 \%$ co-transducible with thi $(90 \mathrm{~min})$, but only $34 \%$ with $\arg C(89 \mathrm{~min})$. Tolerance of NL in the spontaneous $E$. coli $\mathrm{K} 12$ mutants was solely linked to met $K$, since the resistance markers of the phenotypes $\mathrm{NL}^{\mathrm{R}}, \mathrm{NL}^{\mathrm{R}} \mathbf{M M}^{\mathrm{R}}$, $\mathrm{NL}^{\mathrm{R}} \mathrm{Et}^{\mathrm{R}}$ or $\mathrm{NL}^{\mathrm{R}} \mathrm{Et}^{\mathrm{R}} \mathrm{MM}^{\mathrm{R}}$ were co-transduced simultaneously with serA $(63 \mathrm{~min})$ and galP $(64 \mathrm{~min})$. Thus all the spontaneous $\mathrm{NL}^{\mathrm{R}}$ mutants with different phenotypes belong to the same met $K$ genotype. However, $N^{R} M^{R} M^{R} E^{R}$ mutants obtained by NTG mutagenesis were interesting. One group was characterized as met $K$ 
whereas another group was found to have mutations at both $m e t J$ and $m e t K$ loci. Thus it was found that the mutants selected by MM and Et had mutations in the $O$ (succinyl)homoserine synthase (metA) and methionine regulatory $(m e t)$ genes respectively. All the mutants selected in presence of NL uniformly had mutations in the methionine adenosyltransferase ( $m e t K$ ) gene, though they had varied analogue resistance.

Activity of NL on in vitro adenosylation of methionine by E. coli K12 enzyme

It was puzzling that NL, which was shown to have no activity on in vitro adenosylation of methionine by $E$. coli enzyme (Cox \& Smith, 1969), could select mutants with altered enzyme activity for the same reaction (Greene $e t$ al., 1973). ATP :L-methionine-S-adenosyl transferase of $E$. coli was reported to be different from that of Saccharomyces cerevisiae, which was activated by the product AdoMet and inhibited by NL at low methionine concentration (Chou \& Talalay, 1972). None of these properties could be detected in the purified enzyme from E. coli (Markham et al., 1980).

The present study using spontaneously occurring methionine-analogue-resistant mutants of $E$. coli $\mathrm{K} 12$ strongly suggested that NL might have a direct role in the synthesis of AdoMet. All the mutants with different phenotypes selected in presence of NL were found to be $m e t K$ and none of them had any mutation at met $J$ with respect to AdoMet affinity. So the kinetics of AdoMet synthesis were restudied using an enzyme preparation (see Methods). In the synthesis of AdoMet using the same amounts of cell protein $(40 \mu \mathrm{g})$ and ATP $(16 \mathrm{mM})$, two distinctly different kinetics were observed in presence of two different concentrations of $\left[{ }^{35}\right.$ S]methionine, 7.77 and $0.77 \mathrm{mM}$ (Fig. 4). Kinetics of [ ${ }^{35}$ S]AdoMet synthesis, studied for $60 \mathrm{~min}$ with $7.7 \mathrm{mM}$ methionine, were similar to those reported by Markham et al. (1980). Presence of NL (20 molar excess over methionine) had no effect on the adenosylation. However, the kinetics changed significantly when the methionine concentration was reduced 10 -fold under the same experimental conditions. The kinetics were found to be similar to those observed for the yeast enzyme (Chou \& Talalay, 1972). The characteristic lag phase in the synthesis of AdoMet by the enzyme was observed up to $5 \mathrm{~min}$ of incubation. The addition of $0.16 \mathrm{~mm}$-AdoMet to the incubation mixture reduced the lag phase to $2 \mathrm{~min}$, and $0.32 \mathrm{~mm}$ AdoMet abolished the lag phase completely. Presence of $\mathrm{NL}$ at 20 molar excess over methionine in the incubation mixture affected AdoMet synthesis by extending the lag phase from 5 to $10 \mathrm{~min}$ and partially lowering subsequent adenosylation throughout the incubation period, compared to a control containing no NL. Addition of

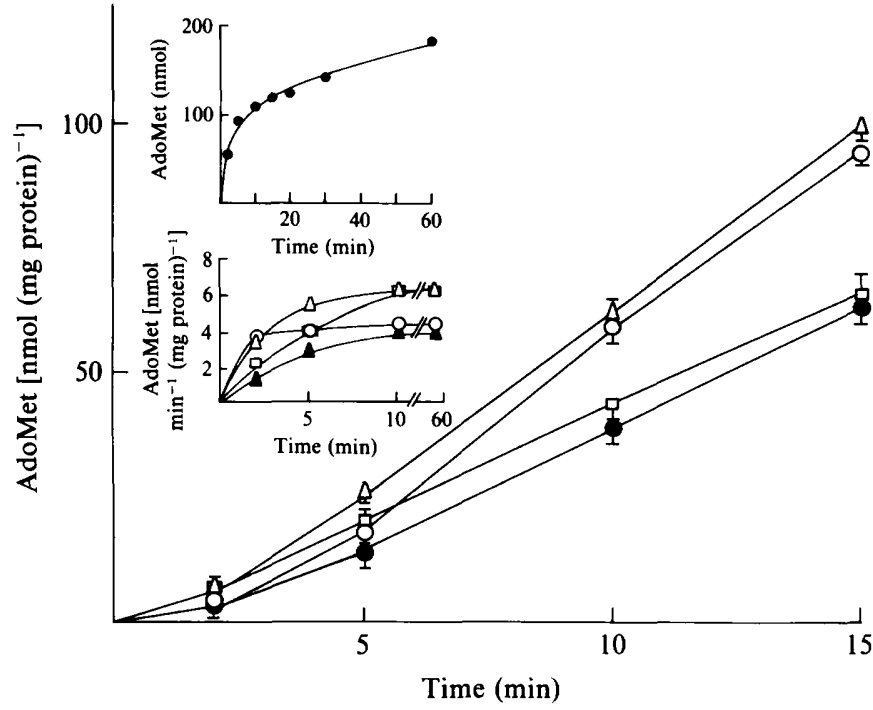

Fig. 4. Kinetics of $S$-adenosylation of $\mathrm{L}$-methionine by the $E$. coli $\mathrm{K} 12$ enzyme in the presence of NL. The reaction was conducted with two different concentrations $(7.7 \mathrm{mM}$ and $0.77 \mathrm{mM})$ of $\left[{ }^{35}\right.$ S]methionine $\left(0.92 \mathrm{Ci} \mathrm{mol}^{-1}\right)$. Other components of the reaction mixture were as described in the legend to Fig. 3. NL was added in 20 molar excess ( $15 \cdot 4$ $\mathrm{mM}$ ) over methionine. AdoMet concentration was $0.16 \mathrm{~mm}$. The reaction was terminated at various times and $\left[{ }^{35} \mathrm{~S}\right]$ Adomet generated was recovered as described in Materials and Methods. $O$, methionine $(0.77 \mathrm{mM}) ; \triangle$, Adomet $(0.16 \mathrm{~mm})+$ methionine $0.77 \mathrm{~mm}) ; \square$, Adomet $(0.16 \mathrm{~mm})+$ methionine $(0.77 \mathrm{~mm})+\mathrm{NL}(15.4 \mathrm{~mm})$. The error bars indicate $\pm \mathrm{SD}$ of three sets of duplicate experiments. Insets: $\bullet$, Methionine (7.7 mM); $\triangle$, AdoMet (0.16 mM) + methionine (0.77 mM); $\square$, methionine $(0.77 \mathrm{~mm}) ; 0$, AdoMet $(0.16 \mathrm{mM})+$ methionine $(0.77 \mathrm{~mm})+\mathrm{NL}(15.4 \mathrm{mM}) ; \Delta$, methionine (0.77 mM) + NL (15.4 mM)

AdoMet to the incubation mixture containing NL reduced the lag period for adenosylation to $5 \mathrm{~min}$ but did not improve the adenosylation rate lowered by NL. It appeared that NL did not have marked inhibitory activity on the AdoMet activation of the enzyme, but inhibited methionine adenosylation by the enzyme. The enzyme present in met $K$ mutants probably had a modified methionine-binding site resistant to interference by $\mathrm{NL}$, but the enzyme thus modified possibly either could not adenosylate methionine at a rate similar to the native enzyme or could not bind the substrate efficiently. Hobson \& Smith (1973) either identified met $K$ mutants possessing AdoMet synthetase with high $K_{\mathrm{m}}$ or with undetectable activity. Comparative studies of purified enzymes from the wild-type and met $K$ mutants might reveal precisely the modifications that can occur in the enzyme.

\section{Conclusions}

The observations in the present study may be summarized as follows:

1. Et is adenosylated in E. coli $\mathrm{K} 12$ to generate AdoEt, 
which might be the false co-repressor for the methionine regulon.

2. Tolerance of increasing concentrations of NL by $E$. coli $\mathrm{K} 12$ mutants is expressed serially as phenotypes $\mathrm{NL}^{\mathrm{R}} \rightarrow\left(\mathrm{NL}^{\mathrm{R}} \mathrm{Et}^{\mathrm{R}}\right.$ or $\left.\mathrm{NL}^{\mathrm{R}} \mathrm{MM}^{\mathrm{R}}\right) \rightarrow \mathrm{NL}^{\mathrm{R}}, \mathrm{MM}^{\mathrm{R}}, \mathrm{Et}^{\mathrm{R}}$, the genotype being $m e t K$ in all cases.

3. Participation of both methionine and AdoMet in the feedback inhibition of homoserine succinylation in E. coli $\mathrm{K} 12$ as indicated by Lee et al. (1966) was further supported.

4. $\mathrm{NL}^{\mathrm{R}} \mathrm{MM}^{\mathrm{R}} \mathrm{Et}^{\mathrm{R}}$ mutants of $E$. coli $\mathrm{K} 12$ consisted of at least two genotypes, met $K$ and $m e t K$ met $J$.

5. The AdoMet-synthesizing enzyme of $E$. coli $\mathrm{K} 12$ is similar to that of $S$. cerevisiae, and methionine adenosylation by $E$. coli enzyme is partially inhibited by NL when methionine is present at low concentration.

6. The phenotypes of different NL resistant mutants affected in met $K$ could be explained on the basis of the present investigation. NL affects AdoMet synthase in $E$. coli. $\mathrm{NL}^{\mathrm{R}}$ mutants with low AdoMet synthetase could not adenosylate Et efficiently to generate sufficient AdoEt to either repress methionine biosynthesis $\left(\mathrm{NL}^{\mathrm{R}} \mathrm{Et}^{\mathrm{R}}\right)$ or effectively inhibit homoserine succinylase with methionine $\left(\mathrm{NL}^{\mathrm{R}} \mathrm{MM}^{\mathrm{R}}\right)$ or both $\left(\mathrm{NL}^{\mathrm{R}} \mathrm{Et}^{\mathrm{R}} \mathrm{MM}^{\mathrm{R}}\right)$.

\section{References}

Adelberg, E. A., Mandel, M. \& Chen, G. C. C. (1965). Optimal conditions for mutagenesis by $N$-methyl- $N^{\prime}$-nitro- $N$-nitroso guanidine in Escherichia coli K12. Biochemical and Biophysical Research Communications 18, 788-795.

BACHMANN, B. J. (1983). Linkage map of Escherichia coli K12 (edition 7) Microbiological Reviews 47, 180-230.

Chou, T. C. \& Talalay, P. (1972). The mechanism of $S$-adenosylmethionine synthesis by purified preparations of baker's yeast. Biochemistry 11, 1065-1073.

Cox, R. \& SMITH, R. C. (1969). Inhibition of $S$-adenosyl methionine formation by analogues of methionine. Archives of Biochemistry and Biophysics 129, 615-619.

Davis, B. D. \& Mingloli, E. S. (1950). Mutants of Escherichia coli requiring methionine or vitamin $B_{12}$. Journal of Bacteriology 60, 1728.

DEV, I. K. \& HARVEY, R. J. (1984). Role of methionine in the regulation of the synthesis of serine hydroxymethyl transferase in Escherichia coli. Journal of Biological Chemistry 259, 8402-8406.

Glazer, R. I. \& Peale, A. L. (1978). Measurement of $S$-adenosyl-Lmethionine level by SP-Sephadex chromatography. Analytical Biochemistry 91, 516-520.
Greene, R. C., Su, C. H. \& Holloway, C. T. (1970). S-adenosyl methionine synthetase deficient mutants of Escherichia coli $\mathrm{K} 12$ with impaired control of methionine biosynthesis. Biochemical and Biophysical Research Communications 38, 1120-1126.

Greene, R. C., Hunter, J.S. V. \& CoCH, E. H. (1973). Properties of met $K$ mutants of Escherichia coli $\mathrm{K} 12$. Journal of Bacteriology 115, 5767.

Greene, R. C. \& Radovich, C. (1975). Role of methionine in the regulation of serine hydroxymethyl transferase in Escherichia coli. Journal of Bacteriology 124, 269-278.

Hobson, A. C. \& Smith, D. A. (1973). S-adenosyl methionine synthetase in methionine regulatory mutants of Salmonella typhimurium. Molecular and General Genetics 126, 7-18.

Kung, H. F., Spears, C., Greene, R. C. \& Weissbach, H. (1972). Regulation of terminal reactions in methionine biosynthesis by vitamin $\mathrm{B}_{12}$ or methionine. Archives of Biochemistry and Biophysics 150, 23-31.

LeE, L. H., Ravel, J. M. \& Shive, W. (1966). Multimetabolite control of a biosynthetic pathway by sequential metabolites. Journal of Biological Chemistry 241, 5479-5480.

MARKHAM, G. D., HAFNER, E. W., TABOR, C. W. \& TABOR, H. (1980) $S$-Adenosylemethionine synthetase from Escherichia coli. Journal of Biological Chemistry 255, 9082-9092.

Martin, W. R. \& Moo-PenN, W. F. (1963). Studies on the mechanism of Escherichia coli resistance to ethionine. Proceedings of the Society for Experimental Biology and Medicine 114, 666-669.

MEedel, T. H. \& PIZER, L. I. (1974). Regulation of one carbon biosynthesis and utilization in Escherichia coli. Journal of Bacteriology 118, 905-910.

MiLlER, J. H. (1972). Experiments in Molecular Genetics, Cold Spring Harbor, NY: Cold Spring Harbor Laboratory.

PARK, L. W. (1958). S-Adenosylethionine and ethionine inhibition. Journal of Biological Chemistry 232, 169-176.

PETERKofSKy, A. (1965). Alteration of the macromolecular structure of nucleic acid by transmethylation. In Transmethylation and Methionine Biosynthesis, pp. 115-137. Edited by S. K. Shapiro \& F. Schlenk. Chicago, Illinois: University of Chicago Press.

SCHLESINGER, S. (1967). Inhibition of growth of Escherichia coli and of homoserine $O$-transsuccinylase by $\alpha$-methylmethionine. Journal of Bacteriology 94, 327-332.

Shoeman, R., Redfield, B., Coleman, T., Greene, R. C., Smith, A. A., Brot, N. \& WeissBaCh, H. (1985a). Regulation of methionine synthesis in Escherichia coli: effect of metJ gene product and $S$ adenosylmethionine on the expression of the met $F$ gene. Proceedings of the National Academy of Sciences of the United States of America 82, 3601-3605.

Shoeman, R., Coleman, T., Redfield, B., Greene, R. C., Smith, A. A., Saint-Girons, I., Brot, N. \& Weissbach, H. (1985b). Regulation of methionine synthesis in Escherichia coli: effect of met $J$ gene product and $S$-adenosylmethionine on the in vitro expression of met $B$, met $L$ and metJ genes. Biochemical and Biophysical Research Communications 133, 731-739.

SMiтH, D. A. (1971). S-Amino acid metabolism and its regulation in Escherichia coli and Salmonella typhimurium. Advances in Genetics 16, 142-161

Su, C. H., Greene, R. C. \& Holloway, C. T. (1970). Regulation of $S$ adenosyl methionine synthetase in Escherichia coli K12. Bacteriological Proceedings 70, 136.

TABOR, H. \& TABOR, C. W. (1971). Enzymatic synthesis of radioactive S-adenosyl-L-methionine. Methods in Enzymology 17B, 393-397. 